\title{
Towards personalized persuasive strategies for active ageing
}

\author{
Carlijn Valk MSc ${ }^{\mathrm{a}, *}$
}

Yuan Lu PhD

Xipei Ren $\mathrm{MSc}^{\mathrm{a}}$

Marjolein Wintermans MSc ${ }^{a}$

Ivar Kraaijevanger MSc ${ }^{\mathrm{a}}$

Jim Steenbakkers MSc ${ }^{\mathrm{a}}$

\begin{abstract}
Vincent Visser BSc ${ }^{\mathrm{a}}$
${ }^{a}$ Faculty of Industrial Design, Eindhoven University of Technology, Eindhoven, The Netherlands; *Corresponding author: c.a.I.valk@tue.nl

C. Valk, Y. Lu, X. Ren, M. Wintermans, I. Kraaijevanger, J. Steenbakkers, V. Visser. Towards personalized persuasive strategies for active ageing. Gerontechnology 2017;16(3):160172; https://doi.org/10.4017/gt.2017.16.3.005.00 As Europe is ageing, the healthcare system is experiencing dramatic strain. Increasing physical activities is important to promote independent living among seniors due to its impact in preventing chronic diseases and long-term care. Smart wearable technologies have been already developed to support citizens to be more physically active. However, the impact of these wearable technologies on seniors is still requires more research. Persuasive system design (PSD) strategies may be applied to motivate seniors to adopt a more active lifestyle. This paper examines 12 student team design concepts which aim to add values to one existing wearable product by redesigning the accompanying application to suit an elderly user group using the PSD principles. From clustering the resulting re-design concepts, we identified themes, suggesting values suitable for an elderly user group that aim to stimulate a more active lifestyle. Furthermore, we identified common persuasive principles applied to redesign concepts in each value theme so as to create design guidelines for active ageing lifestyle.
\end{abstract}

Keywords: active ageing, behavior change, persuasive strategies, personalization, physical activity

\section{BACKGROUND}

Trends in aging

The European Council recognizes the need to address Europe's growing population of senior citizens, caused by the rise in life expectancy and decreased fertility rates ${ }^{1}$. The World Health Organization (WHO) projects the population percentage of seniors in Europe to rise from 14\% in 2010 to $24 \%$ in $2050^{2}$. This rapid growth of the ratio of senior citizens, aged 65 and above, to working-aged citizens, will put increased pressure on Europe's healthcare systems which are mainly funded by working-age taxpayers ${ }^{1,3}$. Senior citizens are the most expensive population group for the health care system and their numbers rise faster than those working-tax payers who finance Europe's health care systems1. Thus, addressing the high costs associated with health care in older age can potentially solve Europe's approaching health care cost dilemma ${ }^{4}$.
Adopting a more active lifestyle is one of the surest, "means of postponing the onset of functional decline, promoting independence, and maintaining a high quality of life in old age $\mathrm{e}^{\prime 5}$, while sedentary behavior will have negative health consequences ${ }^{9-11}$. Despite these clear health benefits, the senior population currently displays the most sedentary behavior, of any age group ${ }^{6,7}$, often spending about $80 \%$ of their waking hours in an idle manner ${ }^{8}$. The challenge is how to motivate seniors to adopt a more active lifestyle, increase this population's independence, improve their quality of life and ultimately decrease high cost of care.

The need to implement persuasive strategies to stimulate seniors to adopt a more active lifestyle is clear. Earlier related work emerges a strong indication that the application of persuasive strategies should be personalized to 
improve the likelihood of the target behavior being adopted ${ }^{12-15}$. Though much is written on the need for personalizing persuasive messages to match the user's motivational and psychological profile, it is unclear how strategies for persuasive or motivational messages can be applied to suit the specific and personalized needs of the user. This personalization is particularly important for the senior population, due to their largely varying needs ${ }^{13,16,17}$. LeRouge et al. highlighted the fact that, "the process of capturing the mental model of the aged patients such that it can be used to inform the design decision of health products is yet not well articulated in research and practice ${ }^{\prime \prime 13}$. This paper will describe and discuss an initial study intended to generate design strategy suggestions for further research, and aims to contribute to a better understanding of how to apply the personalization of persuasive strategies for behavior change, especially for seniors.

\section{Demographics of senior citizens}

The European Commission published that the overall fertility rate in Europe is projected to increase from 1.59 in 2013 to 1.68 by 2030 and 1.76 by 2060 , but will remain below 2.1, the natural population replacement rate $^{4}$. In addition, life expectancy in the EU is projected to increase 7.1 years for men and 6 years for women, between 2015 and 2060 ${ }^{1}$. From this it is clear that Europe will need to address the challenges that come with health in older age.

The European Commission ${ }^{1}$ has identified that demand for care, and thus care-related expenses, increases with age as seniors are more likely to suffer multiple comorbid conditions and chronic diseases, such as frailty which inhibits their independence and increases their need for care. These findings are echoed by Sneha ${ }^{18}$ and LeRouge ${ }^{13}$. The EU will see a substantial increase in public spending on long-term care for seniors; between 2007 and 2060 public spending will almost double from $1.2 \%$ to $2.3 \%$ of GDP in the $\mathrm{EU}^{4}$. This increased demand for medical care with age can in part be explained by the relative lack of successful medical innovations to treat chronic diseases, despite advances made to decrease the number of fatal diseases ${ }^{19}$. Also, the changing ratio between senior citizens and working-aged taxpayers poses a financial issue. By 2060, the number of working-age adults for every person 65 years of age and older will have decreased from the present four to only two, overtaxing the current healthcare system?

As European member states cut public spending on professional care homes for their seniors, strain and stress on family and other informal care providers who step in to replace formal care increases ${ }^{1,20}$. Muscle weakness, poor balance, and low bone density among other prevalent symptoms of frailty threaten a senior's independence and self-sufficiency $y^{5}$ and increase their dependence on care. Physical activity has been shown to maintain muscle strength and bone density and improve the physical functioning required for activities of daily living ${ }^{21}$. Physical activity has been found to have a positive effect on social involvement, self-esteem, stress reduction, cognitive function, maintain bone density and muscle strength, and chronic disease risk reduction ${ }^{21}$. Increased physical activity in seniors has been shown to not only improve psychological well-being and overall quality of life but also to prolong independence of care ${ }^{11}$. In contrast, sedentary behavior has been linked to coronary disease, type two diabetes, breast cancer, colon cancer and other causes of premature mortality ${ }^{22}$. Activating Europe's senior population will, "not only increases healthy life expectancy and postpones much health expenditure but [will] also [have] wider economic benefits" ${ }^{\prime 4}$. Prolonged healthy life expectancy incentivizes people to invest in the development of skills and to postpone retirement $^{4}$. Enabling seniors to remain independent longer, by stimulating physical activity will not only decrease the care related costs associated with falling and other symptoms of frailty but will likely improve their quality of life through affording them more independence and reducing strain on informal care providers.

To summarize, although there is no way to prevent the natural decline that comes with aging, an increase in physical activity can make seniors happier and healthier, improve the senior population's quality of life by affording them longer independence and thus reduce health care cost. The question remains: how can we motivate the senior population to adopt a more active lifestyle?

\section{Design for behavior change}

Behavior change is difficult to achieve and especially, to maintain. In the past researchers have attempted to define strategies to stimulate people to achieve and maintain their target behavior.

Much of the existing literature focuses on describing the psychological elements that lead to behavior change. Ryan and Deci's Self Determination theory describes three different motivators correlating to three innate human needs; competence (feeling over control over one's situation), relatedness (feeling of connectedness to others), and autonomy (feeling of free will) ${ }^{23}$. Ryan and Deci ${ }^{23}$ describe basic human needs which may act as motivators; these fundamental motivators are not easy to 
translate into practical strategies toward design for behavior change. In our continued search for relevant frameworks we found Prochaska and Velicer's Trans-Theoretical Model (TTM) ${ }^{24}$ of behavior change both descriptive and actionable. The TTM describes behavior change as a process over time with various stages of openness to adapting to new behavior, from ambivalence to determination ${ }^{24}$. The TTM allows designers to gain a better understanding of the dynamic state of mind their user is in when moving through the process of behavior change. This model does not provide suggestions as to how to match user needs in each of these stages with the appropriate design strategies.

Fogg's Behavior Model ${ }^{25}$ describes what must occur to induce the user to perform a target action, and includes designer suggestions. Fogg's model proposes that the likelihood of adoption of the desired behavior is related to the user's motivation to complete the task, and their ability to do $\mathrm{so}^{25}$. Fogg ${ }^{25}$ determined that the higher an individual's motivation, the more inclined they will be to take action, even if the task is difficult. Fogg 25 also asserted that if an individual's motivation is low and the target behavior needs to require very little effort, individual's ability needs to be high, for the individual to perform the behavior ${ }^{25}$. Although Fogg's valuable insights establish some notion of requirements for triggering behavior, this model does not provide strategies about how to create fitting triggers applicable to design work for senior users.

More focusing on defining design applications, the Behavior Change Wheel, a framework for characterizing and designing behavior change interventions by Michie ${ }^{26}$, suggests that different behavior change design policies can be implemented through any of Michie's identified interventions. The outermost ring of the Behavior Change Wheel is called policies and refers to drivers from responsible parties, which enable or facilitate interventions, targeting behavior change ${ }^{26}$. Unfortunately, none of the above frameworks provide concrete strategies for applying interventions in projects aimed at stimulating seniors to be more physically active.

Other literature is highly specific in providing concrete suggestions about how to attain lasting behavior change. Culos-Reed ${ }^{27}$ writes on the Predictors of Adherence to Behaviour Change Interventions in the Elderly and describes determinants of an individual's likelihood of following through with a healthier lifestyle. Culos-Reed ${ }^{27}$ states that self-efficacy and past exercise habits are the most important indicators of whether an individual will adopt the target behavior and that social support plays a

major role in adopting new habits of increased physical activity and diet.

Consolvo ${ }^{28}$ describes design strategies for lifestyle behavior change technologies. Characteristics of effective behavior change design should, according to Consolvo ${ }^{28}$, be abstract enough to encourage the user to reflect, be unobtrusive to user's other activities, not be objectionable to the user if shared in a public space, be attractive and aesthetic, be positive, allow the user to have ownership of the system, allow user to track their change over time, and be comprehensive enough to address a variety of user needs related to their changing behavior ${ }^{28}$. Consolvo ${ }^{28}$ provides significant insights into the needs of users in terms of behavior change, however the strategies proposed might be better suited to function as overall design requirements, rather than a systemic overview of design approach strategy, as these high-level concepts can still be challenging to implement in a design process.

Oinas-Kukkonen and Hajumaa ${ }^{29}$ provide clear, persuasive strategies in their article, Persuasive Systems Design (PSD). They outline four main system qualities (Primary Task Support, Dialogue Support, System Credibility Support, and Social Support). Each of these principles is further divided into descriptive design principles, referred to as persuasive principles. These persuasive principles can be used to classify the motivational drivers behind products, which aim to change user behavior toward a healthier lifestyle. This paper is interested to research how these persuasive principles can be applied to create motivational drivers to promote physical activities among senior citizens.

Previous work to facilitate behavior change targeted towards an already motivated audience, such as a running application for already dedicated runners, often depend on the intrinsic motivation of the user and are inappropriate for those yet unmotivated to adopt a healthier lifestyle ${ }^{30}$. The growing population of sedentary seniors is not motivated to engage in enough regular physical activity, and thus likely require a different approach to motivate them to move more. This calls for research actions to explore ways in which persuasive strategies can be applied to adapt existing products, intended for physically active younger adults, to stimulate senior users to adopt a more active lifestyle.

\section{Methodology}

To explore which persuasive principles ${ }^{29}$ should be used to meet the needs of senior citizens to promote physical activity, we conducted multiple case studies of student group design processes. Due to the lack of activity promot- 
ing products specifically targeting a senior audience, we decided to analyze student group design concepts rather than existing products. Student groups re-designed applications, accompanying existing fitness and activity promoting products for younger adults, to be more suitable for senior users. By analyzing which persuasive design principles students applied in their final application re-design concepts to motivate senior citizens to live more actively, we can formulate new hypotheses and design research questions for further investigation.

The case studies were based on 12 student groups design projects. There were two predefined design cases: 1) redesign of Xiaomi Band's $^{31,32}$, a wearable sensor facilitating selfmonitoring accompanied with a mobile application, for senior users to promote physical activity and 2) redesign of the smart sensor mat, HealthSit's accompanied with a mobile application, to prevent sedentary sitting behavior. The HealthSit was designed by $\operatorname{Ren}^{33}$, at the Department of Industrial Design, Eindhoven University of Technology (TU/e), to allow office workers to self-monitor sedentary sitting behavior. The HealthSit prototype consists of six pressure sensors incorporated into a felt mat, which registers the sitting posture ${ }^{33}$.

The setup of these design cases was achieved in a multidisciplinary Bachelor course for first and second-year students at the TU/e. This course aimed to teach students different market research methods and identify design opportunities through actively working in pre-defined design cases. At the start of the 4-week course from 17 November2016 until 12th December 2016, 78 students were divided into 12 multidisciplinary groups of five to seven students per group from different disciplines. Table 1, Group Distributions, below provides the group information and the related design case. Six student groups worked with the Xiaomi Mi Band and six student groups worked with the HealthSit.

Table 1. Group distributions

\begin{tabular}{ll}
\hline Product to re-design & Design for senior citizen user group \\
\hline & Group 7 with 7 students \\
& Group 8 with 7 students \\
& Group 9 with 6 students \\
Gensor: HeathSit & Group 16 with 7 students \\
& Group 17 with 7 students \\
& Total: 40 students 6 students \\
\hline & Group 10 with 7 students \\
& Group 11 with 6 students \\
& Group 12 with 5 students \\
Sensor: Xiaomi Mi Band & Group 13 with 7 students \\
& Group 14 with 7 students \\
Group 15 with 6 students \\
Total: 38 students
\end{tabular}
78 students
Each student group followed a similar reflective transformative design process ${ }^{34}$ and took on first, second and third person perspectives ${ }^{35}$. All groups initially used the existing applications themselves, taking on the role of the user. After making some suggestions for redesign from their own perspective, all groups conducted semi-structured interviews with at least one senior user. Senior users never participated in user research with more than one student group for the duration of this design case. From their collected user insights, each of the twelve student groups then created a first design iteration for the redesign of their application. The groups got feedback on their design concepts from a second user interview or user test. Each of the student groups followed a comparable process for this design case.

In order to examine how persuasive strategies can be applied to adapt applications to more closely address the needs of sedentary seniors, the final concept video, presentation and report of each student group were collected and analyzed. The aim of this analysis was to specify how persuasive strategies could be applied to motivate the seniors to be more physically active.

To compare and analyze these concepts of this investigation, the general quality of each concept was examined in a user evaluation. Only concepts with suffice quality will be included in further analysis. Authors made a selection of a set of criteria, based on the 8 dimensions of product quality defined by $\operatorname{Gavin}^{36}$, i.e., performance, feature, reliability, conformance, durability, serviceability, aesthetics, perceived quality, to evaluate the general quality of the concepts appropriate for this context. They determined that the concepts should be appealing to users (aesthetics), encourage physical activity (feature), stimulate continued usage (serviceability), allow room for personalization (feature), be realistic and accessible (serviceability). An independent focus group of potential future users was asked to evaluate each concept based on criteria established by the authors. The focus group members consist of four potential users (Table 2), Focus Group Participants, for more details. One researcher presented concise descriptions of each concept and value while displaying any visual material, like application screenshots or concept video the students provided in their deliverables, to the focus group. Focus group members were asked to rank their agreement with 9 statements related to the criteria specified by the authors. Assuming each of the statements bears equal weight on the quality of the concept we can examine the average of all 9 criteria and use this overall concept score to compare the 
Table 2. Focus group participants

\begin{tabular}{cccc}
\hline $\begin{array}{l}\text { Participant } \\
\text { Number }\end{array}$ & Age & Education & $\begin{array}{c}\text { Number of times } \\
\text { engaged in exercise } \\
\text { weekly }\end{array}$ \\
\hline 1 & 59 & Masters & 5 \\
2 & 54 & $\mathrm{HBO}^{39}$ & 2 \\
3 & 61 & $\mathrm{PhD}^{39}$ & 3 \\
4 & 56 & $\mathrm{MBO}^{39}$ & 2 \\
\hline
\end{tabular}

quality of the concepts. All ratings are on the same Likert scale ${ }^{37}$ except statement 9 which uses an inverted Likert scale ${ }^{37}$. Therefore, the answers from statement 9 were inverted before calculating the average. Concepts with higher than average score were considered with suffice quality. We analyzed these concepts further to identify the implemented persuasive principles through careful examining the submitted final reports, concept videos and presentation slides of the selected concepts. Each concept was also clustered according to the values that they created to promote physical activities. Authors then formulated hypotheses for future research based on the identified persuasive principles applied in each concept and their relation to the resulted values in order to get better understanding on how to create motivational strategies for promoting more physical activities among senior citizens.

\section{Results}

Table 3 and 4, Summary of design concepts, summarize the final concepts and value propositions of each student group. Almost all student groups mentioned at one time the importance of translating the application into the native language of the seniors and using graphical interfaces suitable for seniors, such as easy to read text. These common observations were not discerned in the table below which reports on the student groups' unique concepts unless specific, explicit attention was paid to these elements in the final report.

Table 5, reports on the focus group's average agreement score for each statement. We can conclude that concept 10, 12 and 15 are evaluated as best by users in the focus group and concepts 17 was evaluated as worst but all concepts rank between 2.9 and 4, with 3 being the average possible score. Thus, all concepts were deemed sufficiently similar in quality to be acceptable to include in our analysis.

Through careful examination of the submitted final reports, concept videos and presentation slides each student group contributed, we identified the persuasive principles in each final concept. Initially, this resulted in an extensive list of all the persuasive principles found in each design concept (Table 6). From this list, it

becomes clear that students applied a combination of persuasive principles to adapt activity tracking sensor applications to senior citizens in their final concepts. For example, group 12 combines mostly Primary Task Support and Social Support to create a 'Social Map' where users can see other users in their community and close physical vicinity. Users have the option of reaching out to others to invite them to join activities, which will stimulate a more active lifestyle. In this concept users can also see how their level of activity compares to other users.

Table 6, Persuasive principles in design student concepts, summarizes the persuasive principles found in each design concept. The breakdown of persuasive principles used, shows that primary task support was the most frequently used persuasive category, followed by dialogue support, with credibility support and social support being utilized less frequently.

From the 12 final concepts, it can be observed that many different persuasive strategies were combined. The authors, thus, went on to map all the possible persuasive principle combinations that the student projects yielded. Once the exhaustive list of persuasive principle combinations had been made researchers examined the frequency of each combination. Table 7, Frequent Principle Combinations, summarizes only the most frequently occurring principle combinations. The numbers in the table reflect how many groups used the respective combination of persuasive principles.

The analysis above suggests that a combination of persuasive principles may be used to add value for seniors and motivate them to move more. The design concepts were clustered based on similar added value. This clustering revealed certain themes, suggestive of the values that are sought in projects of this nature, reported in Table 8, Concepts clustered on similar values. Some projects proposed more than one added value. In these cases, these concepts were clustered twice. The theme, Social fitness, refers to concepts that aim to add value to the user experience by creating opportunities for social engagement, which lead to more physical activity. The value proposed from Improved Care is clear; the application promises better quality of care, usually through providing medical professionals with more insight and information. The projects categorized under Prize have some kind of reward system in common, which either refers to discounts or advancements in game applications. Personalized goals and self-monitoring contribute to user selfawareness. Design concepts in Self-awareness focus on enabling the user to monitor their progress, gain more understanding about their goals / per- 
Table 3. Summary of design concepts for Mi Band (note: where student groups did not name their concepts, a title was provided by the authors)

\begin{tabular}{|c|c|}
\hline Student Group & Description of final design concept \\
\hline $\begin{array}{l}\text { Group 10: Pro- } \\
\text { filing "My } \mathrm{Mi} \\
\text { Band and } \mathrm{Me}^{\text {" }}\end{array}$ & $\begin{array}{l}\text { This application is highly personalized to the user. This } \\
\text { system collects user data about physical activity during } \\
\text { an introduction period of several days. The user also } \\
\text { completes a survey to provide more information about } \\
\text { their social contact and motivation style. Users are pro- } \\
\text { filed according to their preference for social interven- } \\
\text { tions against current level of physical activity. The sys- } \\
\text { tem uses this profile to personalize messages including } \\
\text { suggestions, social comparisons, and goal setting. }\end{array}$ \\
\hline
\end{tabular}

This concept consists of a large dashboard screen hung in the common space of the care home on which seniors can see their own and other resident's physical activity, which is translated into fun comparisons to bring the

Group 11: Pub- achievement in perspective: "today you have walked the lic Dashboard

length of the Rotterdam harbor". The system offers nurses of the care home an easy overview to gain insight into how each resident is moving and sleeping. For more detailed information the system will collect and analyze resident behavioral patterns.

This application displays a map locating other users Group 12: So- which allows the user to find, invite and challenge other cial Map users to engage in physical activity together. Third party companies may also implement sponsored locations or coupons to motivate users to plan/take part in activities.

In this concept, personalized goal setting takes the user's mood into account by allowing the user to log their

Group 13: User friendly goal setting

mood. This concept facilitates weekly goal setting based on personal attributes like weight, height, etc. The system allows the user to their activity and sleep log. In this group, particular attention was paid to ease of installation process and color scheme.

This concept paid particular attention to information design and hierarchy to improve the ease of use for the

Group 14: Social scoreboard user. A social score board in this concept allows users to compare their activity with other users in a competitive way. Push notifications vary from tailored statistic updates and motivational messages.

Group 15: Phys- This concept's physical activity event planner allows the ical activity user to plan events and invite other users in their complanner munity.

\section{Value}

The user receives suggestions and goals that are highly personalized for them. Personalized goals and suggestions can support user self-awareness.

Through the suggestions the user can enjoy social activities with other users.

Seniors can reflect their physical activity and enjoy their achievements together with others in a social setting. Seniors can also expect improved from more informed care professionals. . 
Table 4. Summary of design concepts for HealthSit (note: where student groups did not name their concepts, a title was provided by the authors)

\begin{tabular}{|c|c|c|}
\hline Student Group & Description of final design concept & Value \\
\hline $\begin{array}{l}\text { Group 7: Game } \\
\text { advancement } \\
\text { through physical } \\
\text { activity }\end{array}$ & $\begin{array}{l}\text { This concept pays much attention to ease of use in clear } \\
\text { visual communication a graphical representation of user data } \\
\text { for self-monitoring. It includes an option to get professional } \\
\text { advice on behavior and alerts senior users when they have } \\
\text { been sitting too long. To trigger seniors to follow suggestions } \\
\text { to more movement or change their position, this concept } \\
\text { suggests a collaboration with popular digital game and puz- } \\
\text { zle applications. When the suggestion is followed, seniors } \\
\text { gain some advancement in the game in the game/puzzle } \\
\text { application. }\end{array}$ & $\begin{array}{l}\text { With this application seniors } \\
\text { earn achievements in their } \\
\text { game application and can } \\
\text { consult trusted professionals } \\
\text { about questions and to get } \\
\text { suggestions. }\end{array}$ \\
\hline $\begin{array}{l}\text { Group 8: HealthSit } \\
\text { as game controller }\end{array}$ & $\begin{array}{l}\text { In this concept, graphical changes are made to make graph- } \\
\text { ical history of collected data clearer. Here, active sitting on } \\
\text { the HealthSit mat used as game controller for Wiifit and to } \\
\text { turn pages of an E-reader. Reminders can be set, aimed to } \\
\text { trigger interaction and game play. }\end{array}$ & $\begin{array}{l}\text { Clear visuals allow users to } \\
\text { gain insight into their sitting } \\
\text { habits. Seniors play games } \\
\text { on the TV and sit actively } \\
\text { while reading from their e- } \\
\text { reader. }\end{array}$ \\
\hline $\begin{array}{l}\text { Group 9: Credible } \\
\text { System }\end{array}$ & $\begin{array}{l}\text { This concept stresses the need for a clear visual and auditory } \\
\text { interface suited to the visible impaired. It allows user options } \\
\text { regarding push notification reminders and grades user's } \\
\text { sitting behavior daily, on a five-point star scale. This applica- } \\
\text { tion is intended to help senior together with their doctor to } \\
\text { keep track of their movement. Adherence to target behavior } \\
\text { earns user discount on health insurance. }\end{array}$ & $\begin{array}{l}\text { Seniors earn discounts on } \\
\text { health insurance while } \\
\text { receiving more continuous } \\
\text { care and attention from their } \\
\text { care provider. }\end{array}$ \\
\hline $\begin{array}{l}\text { Group 16: App for } \\
\text { Physiotherapist }\end{array}$ & $\begin{array}{l}\text { This concept includes a controller module for seniors with- } \\
\text { out smartphones to use the HealthSit app. Collected data is } \\
\text { shared visually with a physiotherapist via an application } \\
\text { designed for professionals of this profession to gain more } \\
\text { insight into their patients' health conditions. The module for } \\
\text { seniors can communicate alerts and praise. }\end{array}$ & $\begin{array}{l}\text { Seniors can expect more } \\
\text { complete care from more } \\
\text { informed physiotherapists. }\end{array}$ \\
\hline $\begin{array}{l}\text { Group 17: Sharing } \\
\text { app }\end{array}$ & $\begin{array}{l}\text { This application supports user self-monitoring though a } \\
\text { summary of activity and includes a chat function in which } \\
\text { users can chat and share their data with friends. This system } \\
\text { hopes that sharing will lead to planning social physical activ- } \\
\text { ities. This system provides warnings when user has been } \\
\text { sitting too long or sitting in the wrong position. }\end{array}$ & $\begin{array}{l}\text { Seniors can share and dis- } \\
\text { cuss their data with other } \\
\text { users. In this chat function, } \\
\text { seniors can also invite/be } \\
\text { invited to join activities with } \\
\text { friends. }\end{array}$ \\
\hline $\begin{array}{l}\text { Group 18: Sitting } \\
\text { competition }\end{array}$ & $\begin{array}{l}\text { This application redesign allows users to track their behavior } \\
\text { and receive grades based on a point scale, receive tips creat- } \\
\text { ed by experts, see praise or alarm notifications about behav- } \\
\text { ior, and compete with their family and other users. This } \\
\text { concept emphasizes user-friendliness, simplifying the setup } \\
\text { of sensors due to users' low technology acceptance rate. }\end{array}$ & $\begin{array}{l}\text { Seniors can enjoy praise and } \\
\text { see tips that will help them } \\
\text { do better. They can also } \\
\text { compete with their friends } \\
\text { and family using a perfor- } \\
\text { mance grading system. }\end{array}$ \\
\hline
\end{tabular}

Table 5. Focus Group Comparative Concept Evaluation Score (out of five)

\begin{tabular}{|c|c|c|c|c|c|c|c|c|c|c|c|c|}
\hline & \multicolumn{6}{|c|}{ Mi-band by group numbers } & \multicolumn{6}{|c|}{ HealthSit by group numbers } \\
\hline & 10 & 11 & 12 & 13 & 14 & 15 & 7 & 8 & 9 & 16 & 17 & 18 \\
\hline General Concept Score: & 4.0 & 3.1 & 4.0 & 3.5 & 3.6 & 4.0 & 3.6 & 3.6 & 3.0 & 3.5 & 2.9 & 3.0 \\
\hline I find this concept appealing & 4.3 & 3.8 & 4.5 & 3.0 & 3.5 & 4.8 & 4.0 & 3.8 & 2.5 & 3.5 & 3.3 & 3.0 \\
\hline This concept would encourage me to move more & 4.5 & 2.5 & 4.5 & 3.5 & 3.5 & 3.8 & 3.5 & 3.3 & 3.3 & 3.3 & 3.3 & 2.5 \\
\hline $\begin{array}{l}\text { I can imagine that this concept could encourage } \\
\text { others to move more }\end{array}$ & 4.3 & 3.5 & 4.5 & 3.5 & 3.5 & 4.3 & 3.8 & 4.0 & 3.3 & 3.5 & 2.8 & 3.5 \\
\hline $\begin{array}{l}\text { This concept would also interest me on a long- } \\
\text { term basis }\end{array}$ & 3.8 & 2.5 & 4.3 & 3.0 & 3.3 & 4.3 & 3.5 & 3.3 & 2.5 & 3.5 & 2.3 & 2.3 \\
\hline $\begin{array}{l}\text { This concept could in my opinion also interest } \\
\text { others on a long-term basis }\end{array}$ & 3.8 & 3.5 & 4.3 & 3.3 & 3.5 & 4.5 & 3.3 & 3.8 & 3.0 & 3.5 & 2.8 & 3.0 \\
\hline This concept can be personalized & 4.8 & 2.5 & 3.8 & 4.5 & 4.3 & 4.0 & 4.3 & 3.3 & 4.3 & 4.3 & 3.8 & 3.5 \\
\hline This concept is realistic in my opinion & 4.3 & 3.8 & 3.3 & 3.8 & 4.0 & 4.0 & 3.8 & 4.0 & 3.0 & 3.8 & 3.0 & 3.3 \\
\hline This concept is accessible & 4.0 & 3.5 & 4.3 & 4.0 & 4.0 & 4.0 & 4.0 & 4.3 & 3.5 & 3.8 & 3.3 & 3.3 \\
\hline $\begin{array}{l}\text { There is something about this concept that has to } \\
\text { change to make it work }\end{array}$ & 2.8 & 2.5 & 3.0 & 2.8 & 2.5 & 2.8 & 2.8 & 2.5 & 2.0 & 2.5 & 2.0 & 2.5 \\
\hline
\end{tabular}




\section{Personalized persuasive strategies}

Table 6. Persuasive Principles in Design Student Concepts

\begin{tabular}{|c|c|c|c|c|c|c|c|c|c|c|c|c|c|}
\hline \multirow{3}{*}{ Category } & \multirow{3}{*}{$\begin{array}{l}\text { Persuasive prin- } \\
\text { ciple }\end{array}$} & \multicolumn{6}{|c|}{ Mi-band } & \multicolumn{6}{|c|}{ HealthSit } \\
\hline & & group & group & group & group & group & group & group & group & group & group & group & group \\
\hline & & 10 & 11 & 12 & 13 & 14 & 15 & 7 & 8 & 9 & 16 & 17 & 18 \\
\hline \multirow{7}{*}{$\begin{array}{l}\text { Primary } \\
\text { Task } \\
\text { Support }\end{array}$} & Reduction & & & & & & & & & & & & \\
\hline & Tunneling & & & $\checkmark$ & & & $\checkmark$ & $\checkmark$ & $\checkmark$ & & & $\checkmark$ & $\checkmark$ \\
\hline & Tailoring & & & & & & & & & & & & \\
\hline & Personalization & $\checkmark$ & & $\checkmark$ & $\checkmark$ & $\checkmark$ & $\checkmark$ & $\checkmark$ & $\checkmark$ & & $\checkmark$ & & \\
\hline & Self-monitoring & $\checkmark$ & & & $\checkmark$ & $\checkmark$ & $\checkmark$ & & $\checkmark$ & $\checkmark$ & $\checkmark$ & $\checkmark$ & $\checkmark$ \\
\hline & $\begin{array}{l}\text { Simulation } \\
\end{array}$ & & $\checkmark$ & & & & & & $\checkmark$ & & & & \\
\hline & Rehearsal & & & & & & & & & & & & \\
\hline \multirow{7}{*}{$\begin{array}{l}\text { Credibility } \\
\text { Support }\end{array}$} & Trustworthiness & & & & & & & & & & & & $\checkmark$ \\
\hline & Expertise & $\checkmark$ & $\checkmark$ & & & & & $\checkmark$ & & $\checkmark$ & & & $\checkmark$ \\
\hline & $\begin{array}{c}\text { Surface } \\
\text { credibility }\end{array}$ & & & & & & & & & & & & \\
\hline & Real-world feel & $\checkmark$ & $\checkmark$ & & & & & & & & & & \\
\hline & Authority & & & & & & & $\checkmark$ & & $\checkmark$ & $\checkmark$ & & $\checkmark$ \\
\hline & $\begin{array}{c}\text { Third-party en- } \\
\text { dorsements }\end{array}$ & & & & & & & & & & & & \\
\hline & Verifiability & & & & & & & & & & & & \\
\hline \multirow{7}{*}{$\begin{array}{l}\text { Dialogue } \\
\text { Support }\end{array}$} & $\begin{array}{c}\text { Praise } \\
\end{array}$ & & & & & $\checkmark$ & & & & $\checkmark$ & $\checkmark$ & & $\checkmark$ \\
\hline & Rewards & $\checkmark$ & & & & & & $\checkmark$ & & $\checkmark$ & & & $\checkmark$ \\
\hline & Reminders & & & & & & & & $\checkmark$ & $\checkmark$ & & & \\
\hline & Suggestion & $\checkmark$ & & $\checkmark$ & $\checkmark$ & & & $\checkmark$ & & $\checkmark$ & & & $\checkmark$ \\
\hline & Similarity & & & & & & & & & & & & \\
\hline & Liking & & & & & & & & & & & & \\
\hline & Social role & & & & & & & & & & & & \\
\hline \multirow{7}{*}{$\begin{array}{l}\text { Social } \\
\text { Support }\end{array}$} & $\begin{array}{c}\text { Social } \\
\text { learning }\end{array}$ & & $\checkmark$ & & & & & & & & & & \\
\hline & $\begin{array}{c}\text { Social } \\
\text { comparison }\end{array}$ & & $\checkmark$ & $\checkmark$ & & $\checkmark$ & & & & & & & $\checkmark$ \\
\hline & $\begin{array}{l}\text { Normative } \\
\text { influence }\end{array}$ & & & & & & & & & & & & \\
\hline & $\begin{array}{c}\text { Social } \\
\text { facilitation }\end{array}$ & $\checkmark$ & & $\checkmark$ & & & $\checkmark$ & & & & & $\checkmark$ & $\checkmark$ \\
\hline & Cooperation & & & & & & & & & & & & \\
\hline & Competition & & & & & & & & & & & & $\checkmark$ \\
\hline & Recognition & & & & & & & & & & & & \\
\hline \multirow{8}{*}{ Additional } & Goal-setting & $\checkmark$ & & & $\checkmark$ & & & & & & & & \\
\hline & Sharing & & & $\checkmark$ & & & & & & & & & \\
\hline & Self-logging & & & & $\checkmark$ & & & & & & & & \\
\hline & Notification & & & & & $\checkmark$ & & & & & & & $\checkmark$ \\
\hline & Chat & & & & & & & & & & & $\checkmark$ & \\
\hline & $\begin{array}{c}\text { Negative } \\
\text { reinforcement }\end{array}$ & & & & & & & & & & & & $\checkmark$ \\
\hline & $\begin{array}{c}\text { Economical } \\
\text { benefit }\end{array}$ & & & $\checkmark$ & & & & & & $\checkmark$ & & & \\
\hline & Game & & & & & & & $\checkmark$ & $\checkmark$ & & & & \\
\hline
\end{tabular}

Table 7. Frequent Principle Combinations

\begin{tabular}{|c|c|c|c|c|c|c|c|c|c|}
\hline & \multirow{2}{*}{ Persuasive principle } & \multicolumn{3}{|c|}{ Primary Task Support } & \multicolumn{2}{|c|}{$\begin{array}{c}\text { Credibility Sup- } \\
\text { port }\end{array}$} & \multicolumn{2}{|c|}{ Dialogue Support } & \multirow{2}{*}{$\begin{array}{c}\begin{array}{c}\text { Social } \\
\text { Support }\end{array} \\
\begin{array}{c}\text { Social } \\
\text { comparison }\end{array} \\
\end{array}$} \\
\hline & & Tunneling & $\begin{array}{l}\text { Personali- } \\
\text { zation }\end{array}$ & $\begin{array}{c}\text { Self- } \\
\text { monitoring }\end{array}$ & Expertise & Authority & Praise & Rewards Suggestion & \\
\hline \multirow{2}{*}{$\begin{array}{l}\text { Primary Task } \\
\text { Support }\end{array}$} & Personalization & 4 & & & & & & & \\
\hline & Self-monitoring & 4 & 5 & & & & & & \\
\hline \multirow{2}{*}{$\begin{array}{l}\text { Creditability } \\
\text { Support }\end{array}$} & Expertise & 2 & 2 & 3 & & & & & \\
\hline & Authority & 2 & 2 & 3 & 3 & & & & \\
\hline \multirow{3}{*}{$\begin{array}{l}\text { Dialogue } \\
\text { Support }\end{array}$} & Praise & 1 & 2 & 4 & 2 & 3 & & & \\
\hline & Rewards & 2 & 2 & 3 & 4 & 3 & 2 & & \\
\hline & Suggestion & 3 & 3 & 4 & 4 & 3 & 2 & 4 & \\
\hline Additional & Social facilitation & 4 & 3 & 4 & 2 & 1 & 1 & 2 & 2 \\
\hline
\end{tabular}


Table 8. Concepts clustered on similar values

\begin{tabular}{|c|c|c|c|}
\hline $\begin{array}{l}\text { Value } \\
\text { Themes }\end{array}$ & Group & Value & Strategies combined \\
\hline \multirow{6}{*}{$\begin{array}{l}\text { Social } \\
\text { Fitness }\end{array}$} & $\begin{array}{l}\text { Group 10: Profil- } \\
\text { ing "My Mi Band } \\
\text { and Me" }\end{array}$ & $\begin{array}{l}\text { The user receives suggestions and goals } \\
\text { that are highly personalized for them. Per- } \\
\text { sonalized goals and suggestions can sup- } \\
\text { port user self-awareness. Through the sug- } \\
\text { gestions the user can enjoy social activi- } \\
\text { ties with other users. }\end{array}$ & $\begin{array}{l}\text { Personalization, self-monitor- } \\
\text { ing, expertise, real-world feel } \\
\text { rewards, suggestions, goal } \\
\text { setting, social facilitation }\end{array}$ \\
\hline & $\begin{array}{l}\text { Group 11: Public } \\
\text { Dashboard }\end{array}$ & $\begin{array}{l}\text { Seniors can reflect their physical activity } \\
\text { and enjoy their achievements together } \\
\text { with others in a social setting. Seniors can } \\
\text { also expect improved from more informed } \\
\text { care professionals. }\end{array}$ & $\begin{array}{l}\text { Simulation, Expertise, Real- } \\
\text { world-feel, Social Learning, } \\
\text { Social Comparison }\end{array}$ \\
\hline & $\begin{array}{l}\text { Group 12: Social } \\
\text { Map }\end{array}$ & $\begin{array}{l}\text { Seniors can find friends to join activities. } \\
\text { They may also receive discounts from lo- } \\
\text { cal cafes and museums. }\end{array}$ & $\begin{array}{l}\text { Tunnelling, personalisation, } \\
\text { suggestion, social compari- } \\
\text { son, social facilitation, shar- } \\
\text { ing }\end{array}$ \\
\hline & $\begin{array}{l}\text { Group 15: Physi- } \\
\text { cal Activity Plan- } \\
\text { ner }\end{array}$ & $\begin{array}{l}\text { Senior can invite/ be invited to engage in } \\
\text { physical activities with friends. }\end{array}$ & $\begin{array}{l}\text { Tunnelling, Personalization, } \\
\text { self-monitoring, Social facili- } \\
\text { tation }\end{array}$ \\
\hline & $\begin{array}{l}\text { Group 17: Shar- } \\
\text { ing App }\end{array}$ & $\begin{array}{l}\text { Seniors can share and discuss their data } \\
\text { with other users. In this chat function, } \\
\text { seniors can also invite/be invited to join } \\
\text { activities with friends. }\end{array}$ & $\begin{array}{l}\text { Tunnelling, Self-monitoring, } \\
\text { Social facilitation, chat }\end{array}$ \\
\hline & $\begin{array}{l}\text { Group 18: } \\
\text { Sitting Competi- } \\
\text { tion }\end{array}$ & $\begin{array}{l}\text { Seniors can enjoy praise and see tips that } \\
\text { will help them do better. They can also } \\
\text { compete with their friends and family us- } \\
\text { ing a performance grading system. }\end{array}$ & $\begin{array}{l}\text { Tunnelling, Self-monitoring, } \\
\text { Trustworthiness, expertise, } \\
\text { authority praise, rewards, } \\
\text { suggestion, social compari- } \\
\text { son, social facilitation, com- } \\
\text { petition, notification, chat }\end{array}$ \\
\hline \multirow{3}{*}{$\begin{array}{l}\text { Improved } \\
\text { Care }\end{array}$} & $\begin{array}{l}\text { Group 11: Public } \\
\text { Dashboard }\end{array}$ & $\begin{array}{l}\text { Seniors can reflect their physical activity } \\
\text { and enjoy their achievements together } \\
\text { with others in a social setting. Seniors can } \\
\text { also expect improved from more informed } \\
\text { care professionals. }\end{array}$ & $\begin{array}{l}\text { Simulation, Expertise, Real- } \\
\text { world-feel, Social Learning, } \\
\text { Social Comparison }\end{array}$ \\
\hline & $\begin{array}{l}\text { Group 7: Game } \\
\text { Advancement } \\
\text { through physical } \\
\text { activity }\end{array}$ & $\begin{array}{l}\text { With this application seniors earn } \\
\text { achievements in their game application } \\
\text { and can consult trusted professionals } \\
\text { about questions and to get suggestions. }\end{array}$ & $\begin{array}{l}\text { Tunnelling, personalization, } \\
\text { expertise, authority, rewards, } \\
\text { suggestion, game }\end{array}$ \\
\hline & $\begin{array}{l}\text { Group 9: Credible } \\
\text { System }\end{array}$ & $\begin{array}{l}\text { Seniors earn discounts on health insur- } \\
\text { ance while receiving more continuous } \\
\text { care and attention from their care pro- } \\
\text { vider. }\end{array}$ & $\begin{array}{l}\text { Self-monitoring, expertise, } \\
\text { authority, praise, rewards, re- } \\
\text { minders, suggestion, eco- } \\
\text { nomical benefit }\end{array}$ \\
\hline \multirow{3}{*}{ Prize } & $\begin{array}{l}\text { Group 9: Credible } \\
\text { System }\end{array}$ & $\begin{array}{l}\text { Seniors earn discounts on health insur- } \\
\text { ance while receiving more continuous } \\
\text { care and attention from their care pro- } \\
\text { vider. }\end{array}$ & $\begin{array}{l}\text { Self-monitoring, expertise, } \\
\text { authority, praise, rewards, re- } \\
\text { minders, suggestion, eco- } \\
\text { nomical benefit }\end{array}$ \\
\hline & $\begin{array}{l}\text { Group 12: Social } \\
\text { Map }\end{array}$ & $\begin{array}{l}\text { Seniors can find friends to join activities. } \\
\text { They may also receive discounts from lo- } \\
\text { cal cafes and museums. }\end{array}$ & $\begin{array}{l}\text { Tunnelling, personalisation, } \\
\text { suggestion, social compari- } \\
\text { son, social facilitation, shar- } \\
\text { ing, economic benefit }\end{array}$ \\
\hline & $\begin{array}{l}\text { Group 7: Game } \\
\text { Advancement } \\
\text { through physical } \\
\text { activity }\end{array}$ & $\begin{array}{l}\text { With this application seniors earn } \\
\text { achievements in their game application } \\
\text { and can consult trusted professionals } \\
\text { about questions and to get suggestions. }\end{array}$ & $\begin{array}{l}\text { Tunnelling, personalization, } \\
\text { expertise, authority, rewards, } \\
\text { suggestion, game }\end{array}$ \\
\hline
\end{tabular}


Table 8. Concepts clustered on similar values (continued)

\begin{tabular}{|c|c|c|c|}
\hline $\begin{array}{l}\text { Value } \\
\text { Themes } \\
\end{array}$ & Group & Value & Strategies combined \\
\hline \multirow{4}{*}{$\begin{array}{l}\text { Self- } \\
\text { awareness }\end{array}$} & $\begin{array}{l}\text { Group 10: Profiling } \\
\text { "My Mi Band and } \\
\text { Me" }\end{array}$ & $\begin{array}{l}\text { The user receives suggestions and goals that } \\
\text { are highly personalized for them. Personal- } \\
\text { ized goals and suggestions can support user } \\
\text { self-awareness. Through the suggestions the } \\
\text { user can enjoy social activities with other } \\
\text { users. }\end{array}$ & $\begin{array}{l}\text { Personalization, self-moni- } \\
\text { toring, expertise real-world } \\
\text { feel, rewards suggestions, } \\
\text { goal setting, social facilita- } \\
\text { tion }\end{array}$ \\
\hline & $\begin{array}{l}\text { Group 13: User } \\
\text { friendly goal setting }\end{array}$ & $\begin{array}{l}\text { Seniors receive more attainable, suitable } \\
\text { goals. Seniors can also look back and track } \\
\text { their progress gaining more insight into the } \\
\text { history and progress of their physical active- } \\
\text { ness. }\end{array}$ & $\begin{array}{l}\text { Self-monitoring, Sugges- } \\
\text { tion, goal-setting, self-log- } \\
\text { ging, personalization }\end{array}$ \\
\hline & $\begin{array}{l}\text { Group } 8: \text { HealthSit } \\
\text { as game controller }\end{array}$ & $\begin{array}{l}\text { Clear visuals allow users to gain insight into } \\
\text { their sitting habits. Seniors play games on } \\
\text { the TV and sit actively while reading from } \\
\text { their e-reader. }\end{array}$ & $\begin{array}{l}\text { Tunnelling, personaliza- } \\
\text { tion, self-monitoring, simu- } \\
\text { lation, reminders }\end{array}$ \\
\hline & $\begin{array}{l}\text { Group 17: Sharing } \\
\text { App }\end{array}$ & $\begin{array}{l}\text { Seniors can share and discuss their data } \\
\text { with other users. In this chat function, sen- } \\
\text { iors can also invite/be invited to join activi- } \\
\text { ties with friends. }\end{array}$ & $\begin{array}{l}\text { Tunnelling, Self-monitor- } \\
\text { ing, Social facilitation, chat }\end{array}$ \\
\hline \multirow[t]{2}{*}{ Fun } & $\begin{array}{l}\text { Group } 7: \text { Game ad- } \\
\text { vancement through } \\
\text { physical activity }\end{array}$ & $\begin{array}{l}\text { With this application seniors earn achieve- } \\
\text { ments in their game application and can } \\
\text { consult trusted professionals about ques- } \\
\text { tions and to get suggestions. }\end{array}$ & $\begin{array}{l}\text { Tunnelling, personaliza- } \\
\text { tion, expertise, authority, } \\
\text { rewards, suggestion, game }\end{array}$ \\
\hline & $\begin{array}{l}\text { Group 8: HealthSit } \\
\text { as game controller }\end{array}$ & $\begin{array}{l}\text { Clear visuals allow users to gain insight into } \\
\text { their sitting habits. Seniors play games on } \\
\text { the TV and sit actively while reading from } \\
\text { their e-reader. }\end{array}$ & $\begin{array}{l}\text { Tunnelling, personaliza- } \\
\text { tion, self-monitoring, simu- } \\
\text { lation, reminders }\end{array}$ \\
\hline
\end{tabular}

Table 9. Value themes and Combined persuasive principle strategies

\begin{tabular}{|c|c|c|}
\hline $\begin{array}{l}\text { Value Clusters: } \\
\text { proposed strategies }\end{array}$ & $\begin{array}{c}\text { Combined Persuasive } \\
\text { Categories }\end{array}$ & Combined Strategies \\
\hline Social Fitness & $\begin{array}{l}\text { Primary task support and } \\
\text { Social support }\end{array}$ & $\begin{array}{l}\text { Social-facilitation, self-monitoring, tunnelling, person- } \\
\text { alisation, suggestions }\end{array}$ \\
\hline Improved care & $\begin{array}{l}\text { Primary task support and } \\
\text { credibility support }\end{array}$ & Expertise, suggestions, reward, authority \\
\hline Prize & $\begin{array}{l}\text { Primary task support and } \\
\text { dialogue support }\end{array}$ & Tunnelling, personalization, suggestion \\
\hline Self-awareness & $\begin{array}{l}\text { Primary task support and } \\
\text { dialogues support }\end{array}$ & $\begin{array}{l}\text { Self-monitoring, personalization, expertise, real-world } \\
\text { feel, suggestions, goal setting, social facilitation }\end{array}$ \\
\hline Fun & $\begin{array}{l}\text { Primary task support and } \\
\text { dialogues support }\end{array}$ & Tunnelling, personalization \\
\hline
\end{tabular}

\section{Discussion and Conclusion}

The suggested design strategies and value themes require further investigation. Due to the limited number of student projects it remains difficult to confidently draw design strategies from themes. It also remains unclear how many of the principles should be combined to gain the designed result. However, we suggest that a combination of several principles can enrich the system while isolating combinations of only two principles in further testing might allow the researcher to find more direct links between value creation and persuasive principle application. We suggest further research should test the above-identified design strategies, by apply- ing them to a concept design for senior users intended to motivate them to engage in more physical activities, before drawing any formal conclusions.

A general relative concept evaluation by users was used here because in this investigation, we seek to identify directions for future testing and thus it was only relevant to see that all concepts were of generally equal quality. In future investigations, we suggest further more formal user evaluations of the applied design strategies. Overall, student groups' use of persuasive principles does relate to findings in literature, which often advocates for the use of social devices and 
personalization to motivate senior users ${ }^{13}$ and resonated with the focus group.

Although the obtained results helped us to focus on the potentially relevant persuasive strategies, they failed to help us address the varying needs among the targeted senior population. $\operatorname{Ren}^{33}$ pointed out that different persuasive principles are needed to motivate more physical activities among people with varying levels of support. The Regulatory Focus Theory (RFT) states that people can either be prevention focused, motivated mainly by attaining their 'ought' self, or promotion focused, motivated primarily by attaining the very best version of themselves ${ }^{38}$. The Trans-Theoretical Model of Behavior Change depicts behavior change as a dynamic process with distinct phases ${ }^{24}$. Culos-Reed ${ }^{27}$ claims that an individual's self-efficacy and past exercise behavior can provide an indication of likelihood of an individual's maintenance of adopted behavior such as increased physical activity ${ }^{27}$.

To further investigate how persuasive design strategies can be applied to motivate a senior target group to move more, these separate elements could be combined to create profiles of target users depending on their Regulatory Focus, current stage of change and background in physical activities. The next step is to evaluate the herewith identified strategies applied in a design intending to stimulate a more active lifestyle for groups of seniors profiled according to their $\mathrm{RTF}^{38}, \mathrm{TTM}^{24}$ and fitness background.
Recently, some initial investigations have started to look into to what extent we can profile senior citizens based on the regulatory focus theory and current level of activity. These preliminary investigations will provide us with a baseline to measure the impact of the interventions with the proposed design strategies in this paper, and provide valuable insight into the differences between people who are promotion focused and people who are prevention focused. In a future article, we will report on this further development.

This article conducted a multiple-case study to research whether the persuasive principles based on Oinas-Kukkonen and Harjumaa's Persuasive Systems Design ${ }^{29}$ could be used to motivate more physical activities of the senior users. Twelve student groups used these principles to redesign two existing activity-tracking applications intended for adults who actively engage in physical activity. From analyzing students' work, we have found promising value suggestions relevant to senior users, which need to be investigated further. From the collected data, it was clear that all student design groups utilized a combination of persuasive strategies to add value for this specific user group. The further grouping of how persuasive principles were used to create above mentioned value resulted from suggested design strategies also requires investigation. Future research will focus on developing methods to personalize the identified design strategies to better address a diverse senior user group.

\section{Acknowledgements}

The work presented in this paper was made possible in part by funding from the European Union's Horizon 2020 research and innovation programme under grant agreement No 690425. The authors thank the participating students and participating end users as well as the REACH consortium partners for their contributions to the presented work.

\section{References}

1. European Commission. The 2015 Ageing Report Economic and Budgetary Projections for the 28 EU Member States (2013-2060). Luxembourg, Economic and Financial Affairs 2015

2. World Health Organization Regional Office for Europe. World Health Organization 2017; http://www. euro.who.int/en/health-topics/Life-stages/healthyageing/healthy-ageing; retrieved July 24, 2017

3. Economic Policy Committee and the European Commission (DG ECFIN). The impact of ageing on public expenditure: projections for the EU25 Member States on pensions, health care, longterm care, education and unemployment transfers (2004-2050). European Economy, European Commission Directorate-General for Economic and Fi-

nancial Affairs 2006. Report No.: 1

4. Rechel B, Grundy E, Robine JM, Cylus J, Mackenbach JP, Knai C, McKee M. Health in Europe 6: Ageing in the European Union. The Lancet 2013;381:1312-1322; https://doi.org/10.1016/ S0140-6736(12)62087-X

5. Chodzko-Zajko W, Schwingel A, Park CH. Successful Aging: The Role of Physical Activity. American Journal of Lifestyle Medicine 2009;3(1):20-18; https://doi.org/10.1177/1559827608325456

6. de Rezende LFM, Rey-López JP, Matsudo VKR, Luiz OdC. Sedentary behavior and health outcomes among older adults: a systematic review. BioMed Central 2014; pp 1-9; https://doi.org/10.1186/14712458-14-333

7. Matthews CE, George SM, Moore SC, Bowles HR, Blair A, Park Y, Troiano RP, Hollenbeck A, Schatzkin A. Amount of time spent in sedentary behaviors and causespecific mortality in US adults. The American Journal of Clinical Nutrition 2012;95(2):437445; https://doi.org/10.3945/ajcn.111.019620

8. Davis MG, Fox KR, Hillsdon M, Sharp DJ, Coulson JC, Thompson JL. Objectively Measured Physical Activity in a Diverse Sample of Older Urban UK Adults. Journal of the American College of Sports Medicine 2010;43(4):647-654; https://doi. 
org/10.1249/mss.0b013e3181f36196

9. Dunstan DW, Thorp AA, Healy GN. Prolonged sitting: is it a distinct coronary heart disease risk factor? In Current Opinion in Cardiology 2011;26(5)412-419; https://doi.org/10.1097/ hco.0b013e3283496605

10. Greenwood-Hickman MA, Renz A, Rosenberg DE. Motivators and Barriers to Reducing Sedentary Behavior Among Overweight and Obese Older Adults. The Gerontological Society of America 2016;56(4);660668; https://doi.org/10.1093/geront/gnu163

11. Warburton DER, Nicol CW, Bredin SSD. Health benefits of physical activity: the evidence. Canadian Medical Association Journal 2006;174(6):801809; https://doi.org/10.1503/cmaj.051351

12. Purpura S, Schwanda V, Williams K, Stubler W, Sengers P. Fit4Life: The Design of a Persuasive Technology Promoting Healthy Behavior and Ideal Weight. In CHI 2011; Vancouver: ACM

13. LeRouge C, Ma J, Sneha S, Tolle K. User profiles and personas in the design and development of consumer health technologies. International Journal of Medical Informatics 2013;(82)11:251-268; https://doi.org/10.1016/j.ijmedinf.2011.03.006

14. Higgins ET. Beyond Pleasure and Pain. American Psychologist 1997;52(12):1280-1300; https://doi. org/10.1037//0003-066x.52.12.1280

15. Kaptein M, Markopoulos P, de Ruyter B, Aarts E. Personalizing persuasive technologies: Explicit and implicit personalization using persuasion profiles. International Journal of Human-Computer Studies 2015;77:38-51; https:// doi.org/10.1016/j.ijhcs.2015.01.004

16. Cabrita $\mathrm{M}$, Nassabi $\mathrm{MH}$, op den Akker $\mathrm{H}$, Tabak $M$, Hermens $H$, Vollenbroek $M$. An Unobtrusive System to Monitor Physical Functioning of the Older Adults: Results of a Pilot Study. In International Workshop on Personalization and Adaptation in Technology for Health, PATH 2015 held in conjunction with the 23rd Conference on User Modelling, Adaptation and Personalisation, UMAP 2015; Dublin: PATH 2015; pp 1-12

17. Gregor P, Newell AF, Zajicek M. Designing for Dynamic Diversity - interfaces for older people. In ACM conference on Assistive technologies 2002; Edinburgh: ACM I; pp 151-156; https://doi. org/10.1145/638276.638277

18. Sneha S, Varshney U. Enabling ubiquitous patient monitoring: Model, decision protocols, opportunities and challenges. Decision Support Systems 2009;46(3):606-619; https://doi.org/10.1016/j.dss.2008.11.014

19. European Commission. The 2015 Ageing Report Economic and Budgetary Projections for the $28 \mathrm{EU}$ Member States (2013-2060). Luxembourg: European Commission, Economic and Financial Affairs 2015; https://doi.org/10.2765/877631

20. Christensen K, Doblhammer G, Rau R, Vaupel JW. Ageing populations: the challenges ahead. The Lancet 2009;374(9696):1196-1208; https://doi. org/10.1016/s0140-6736(09)61460-4

21. Bauman A, Merom D, Bull FC, Buchner DM, Fiatarone Singh MA. Updating the Evidence for Physical Activity: Summative Reviews of the Epidemiological Evidence, Prevalence, and Interventions to Promote "Active Aging". The Geron- tologist 2016;56(Suppl 2); pp 268-280; https://doi. org/10.1093/geront/gnw031

22. Lee IM, Shiroma EJ, Lobelo F, Puska P, Blair SN, Katzmarzyk PT. Effect of physical inactivity on major non-communicable diseases worldwide: an analysis of burden of disease and life expectancy. The Lancet 2012;380(9838):219-229; https://doi. org/10.1016/s0140-6736(12)61031-9

23. Ryan RM, Deci EL. Self-Determination Theory and the Facilitation of Intrinsic Motivation, Social Development, and Well-Being. American Psychologist 2000;55(1):6878; https://doi.org/10.1037//0003-066x.55.1.68

24. Prochaska JO, Velicer WF. The Transtheoretical Model of Health Behavior Change. American Journal of Health Promotion 1997;12(1):38-48; https:// doi.org/10.4278/0890-1171-12.1.38

25. Fogg BJ. A Behavior Model for Persuasive Design. Paper. Claremont, California, U.S.A.: Standford University, Persuasive Technology Lab 2009; https://doi.org/10.1145/1541948.1541999

26. Michie $S$, van Stralen MM, West R. The behaviour change wheel: A new method for characterising and designing behaviour change interventions. Implementation Science. 2011;6(1):42; https://doi. org/10.1186/1748-5908-6-42

27. Culos-Reed SN, Rejeski WJ, McAuley E, Ockene JK, Roter DL. Predictors of Adherence to Behavior Change Interventions in the Elderly. Controlled Clinical Trials 2000;21(5):200S-205S; https://doi. org/10.1016/s0197-2456(00)00079-9

28. Consolvo S, McDonald DW, Landay JA. TheoryDriven Design Strategies for Technologies that Support Behavior Change in Everyday Life. In CHI 2009 Creative Though and Self-Improvement 2009; Boston: ACM; pp 405-414; https://doi. org/10.1145/1518701.1518766

29. Oinas-Kukkonen H, Harjumaa M. Communications of the Association for Information Systems. Association for Information Systems 2009;24:485-500

30. Campbell MK, DeVellis BM, Strecher VJ, Ammerman AS, DeVellis RF, Sandler RS. Improving Dietary Behavior: The Effectiveness of Tailored Messages in Primary Care Settings. American Journal of Public Health 1994;84(5):783-787; https://doi. org/10.2105/ajph.84.5.783

31. Xiaomi. Mi 2016; http://www.mi.com/en/miband2/; retrieved August 6, 2017

32. Bindi T. ZDNet 2017; http://www.zdnet.com/article/xiaomi-topples-fitbit-and-apple-as-worlds-largest-wearables-vendor-strategy-analytics/; retrieved August 6, 2017

33. Ren $X$, Visser $V$, Lu $Y$, Brankaert $R$, Offermans S, Nagtzaam H. FLOW Pillow: Exploring Sitting Experience towards Active Ageing. In MobileHCl; Florence: ACM 2016; https://doi. org/10.1145/2957265.2961841

34. Hummels C, Frens J. The Reflective Transformative Design Process. CHI 2009 Design Methods \& Practice; Boston: ACM; pp 2655-2658; https://doi. org/10.1145/1520340.1520376

35. van Beukering A, Donker V, Willemsen M, Lu Y. SED: A non-technological solution to lower the threshold for elderly to accept new technological products and services. 2014; https://pure.tue.nl/ 


\section{Personalized persuasive strategies}

ws/files/16601769/sed_a_non_technological_solution_to_lower_the_threshold_for_elderly_to_ adopt_new_technological_products_and_services.pdf; retrieved October 19, 2017

36. Garvin DA. What Does "Product Quality" Really Mean? Sloan management review 1984; pp 25-43; http://www. oqrm.org/English/What_does_product_quality_really_ means.pdf. reftrieved October 19, 2017

37. Likert R. A Technique for the Measurement of Attitudes. Archives of Psychology 1932;22(140:19321953; https://legacy.voteview.com/pdf/Likert_1932. pdf; retrieved October 19, 2017
38. Brockner J, Higgins TE. Regulatory Focus Theory: Implications for the Study of Emotions at Work. Organizational Behavior and Human Decision Processes 2001;86(1):35-66; https://doi.org/10.1006/ obhd.2001.2972

39. Cooperation Organisation for Vocational Education, Training and the Labour Market (SBB). Vocational Education Labour Market 2017; https://www.s-bb. nl/en/education/dutch-educational-system/complete-description-dutch-educational-system; retrieved August 6, 2017 